\title{
La obediencia como divisa. A propósito de un sermón manuscrito sobre la jura de Agustín I en Zacatecas*
}

\author{
Obedience as a Motto. \\ About a Manuscript Sermon on the \\ Oath of Augustin I in Zacatecas
}

\author{
Josep Escrig Rosa ${ }^{* *}$ \\ (D) https://orcid.org/0000-0001-8976-5998 \\ Instituto de Investigaciones Históricas \\ Universidad Nacional Autónoma de México, México \\ josep.escrig@uv.es
}

Resumen: En este trabajo se analiza un sermón manuscrito de autoría anónima, hasta ahora prácticamente inédito, predicado en Zacatecas el 30 de mayo de 1822, con motivo de la jura de fidelidad a Agustín de Iturbide como

* Este trabajo forma parte del Programa de Becas Posdoctorales de la UnAm, bajo la asesoría de Ana Carolina Ibarra González. Se inscribe en los proyectos de investigación "Entre dos mundos: historia parlamentaria y culturas políticas en los años del Trienio Liberal (1820-1823)" (HAR2016-78769) y "La dimensión popular de la política en la Europa meridional y América Latina, 1789-1898" (PID2019-105071GB-100).

** Doctor en Historia Contemporánea por la Universitat de València. Investigador posdoctoral en el Instituto de Investigaciones Históricas-Universidad Nacional Autónoma de México. Sus líneas de investigación preferentes se centran en el estudio de las culturas políticas contrarrevolucionarias y antiliberales en España y México a comienzos del siglo xIX. Agradezco la lectura y las estimulantes sugerencias de Mariana Terán.

cómo citar: Escrig Rosa, J. (2021). La obediencia como divisa. A propósito de un sermón manuscrito sobre la jura de Agustín I en Zacatecas. Secuencia (111), e1893. DoI: https://doi.org/10.18234/secuencia. v0i111.1893 
emperador electo por parte del Congreso constituyente. El examen propuesto pretende complejizar, desde la perspectiva contrarrevolucionaria y antiliberal, el estudio de los imaginarios monárquicos durante el periodo del primer imperio, así como las distintas representaciones mentales y argumentos teóricos con los que ciertos eclesiásticos sustentaron dicha experiencia de gobierno. El discurso de la lealtad al emperador fue acompañado de una exaltación de Iturbide como caudillo religioso. El predicador aprovechó el momento para exponer su modelo ideal de monarquía y reivindicar un trato privilegiado para el clero, lo cual permite atender a las variables de la alianza Altar-Trono. Supone, por tanto, una aproximación que abre perspectivas de análisis más plurales sobre el contexto de la emancipación mexicana.

Palabras clave: sermón; Zacatecas; Agustín de Iturbide; primer imperio; independencia.

Abstract: This paper analyzes a handwritten sermon of anonymous authorship, until now practically unpublished, preached in Zacatecas on May 30, 1822. It was motivated by the oath of allegiance to Agustín de Iturbide as elected emperor by the Constituent Congress. From the counterrevolutionary and antiliberal perspective, it is intended to enrich the study of monarchical imaginaries during the period of the First Empire. Also, the different mental representations and theoretical arguments with which certain ecclesiastics supported this experience of government. The speech of loyalty to the emperor was accompanied by an exaltation of Iturbide as a religious leader. The preacher exposed his ideal model of monarchy and claimed privileged treatment for the clergy. This allows addressing the variables of the AltarThrone alliance. Therefore, it supposes an approach that opens more plural perspectives of analysis on the context of Mexican emancipation.

Key words: sermon; Zacatecas; Agustín de Iturbide; First Empire; Independence.

Recibido: 31 de agosto de 2020 Aceptado: 20 de octubre de 2020

Publicado: 31 de agosto de 2021 


\section{INTRODUCCIÓN}

T a llegada del militar Agustín de Iturbide al trono del imperio mexicano, L por medio de un golpe de Estado, fue uno de los principales acontecimientos de 1822. Como es sabido, la noche del 18 de mayo una asonada protagonizada por una facción del ejército, el batallón de Celaya -que Iturbide había liderado en el contexto en que se fraguó el proyecto independentista-y sectores populares de la ciudad de México lo exaltaron como emperador. Ante la presión de estos grupos el Congreso constituyente se vio impelido a ratificar dicha elección los días 19 y 21 de ese mes. El solemne acto de coronación en la catedral metropolitana fue previsto para el 27 de junio, pero una indisposición de Iturbide obligó a que se pospusiera hasta el 21 del mes siguiente (Robertson, 2012, pp. 252-266). La historiografía se ha ocupado de los hechos que tuvieron lugar esa jornada, de su simbolismo y del ceremonial que se preparó para dicho evento (Carbajal, 2011; Frasquet, 2008, pp. 200-204; GómezHuerta, 2017; Hensel, 2012; Vázquez Mantecón, 2008, pp. 62-66). También se han analizado los cuatro sermones impresos que se elaboraron para conmemorar tan significativa fecha (Escrig Rosa, 2020; Herrejón, 2008, pp. 153-167).

Este trabajo constituye una nueva aportación al estudio de los discursos religiosos durante el periodo del primer imperio. Para ello se examina un sermón manuscrito, de autoría anónima, predicado en Zacatecas el 30 de mayo de 1822, en presencia de otros eclesiásticos, con motivo de la jura de fidelidad a Iturbide como emperador electo por los diputados del Congreso. Sabemos la fecha en que se pronunció porque, según el orador desconocido, el acto oficial había tenido lugar en dicha población una jornada antes de que él interviniera desde el púlpito, es decir, el día 29. ${ }^{1}$ El documento consta de 28 páginas y se conserva en la sección de manuscritos de la Biblioteca Nacional de España, con la referencia Mss/20243/4 y el título "Sermón al pueblo de Zacatecas para que elija y jure emperador a D. Agustín de Iturbide, con el

${ }^{1}$ Como se verá inmediatamente, las fechas que nos presentó Elías Amador no parecen resultar plausibles en este caso. Según dicho historiador, el 20 de mayo se recibió en Zacatecas la noticia sobre la elección del emperador, algo que resulta inverosímil, pues el Congreso aún estaba discutiendo sobre el particular. Añade que el juramento de fidelidad se realizó en el Convento de San Agustín el día 24, data que también resulta dudosa. Por su parte, la celebración solemne relativa a la coronación tuvo lugar el 25 de diciembre (Amador, 1943, pp. 271-272). 
nombre de Agustín I". ${ }^{2}$ Sólo conocemos un trabajo que haya reparado en esta significativa pieza hasta ahora, aunque, por ejemplo, sin datarla ni, por tanto, prestar atención a su valor hermenéutico dentro del contexto en el que fue pronunciada. Tampoco se ha atendido a las reveladoras fuentes intelectuales de las que se nutrió dicho sermón. Por todo ello, sus posibilidades de análisis no están agotadas (Burciaga Campos, 2011). De entrada, consideramos que resulta relevante por dos motivos.

Por un lado, cabe remarcar que no se trata de una composición religiosa preparada para evocar el momento de la coronación de Iturbide en la catedral de México, pues este acto aún no había tenido lugar. Estamos ante una pieza confeccionada para reclamar fidelidad al emperador que había sido elegido por el Congreso. En este sentido, siempre a falta de nuevas investigaciones y hallazgos, se trata del único sermón del que se tienen noticias que fuera compuesto con esa finalidad específica. ${ }^{3}$ El discurso de la obediencia y de la sujeción a las autoridades constituye el eje argumentativo que lo atraviesa. El pasaje sagrado que abre el manuscrito corresponde a la Epístola $1^{\mathrm{a}}$ de San Pedro 2:15, traducida al castellano por el orador zacatecano como: "Así es la voluntad de Dios; que obrando bien hagáis enmudecer la ignorancia de los hombres imprudentes". Según han señalado los especialistas, en este fragmento se exhortaba a callar las críticas y a respetar las obligaciones según la potestad de Dios, fuente incuestionable de autoridad (Munro, 1983; Ramsey, 1988; Sleeper, 1968). De ello daba cuenta el orador en el exordio. Siguiendo las palabras del apóstol, exponía los motivos para mantenerse subordinados a los gobernantes, en tanto que su capacidad de mando provenía de la Providencia. De esta forma, se sancionaba el orden jerárquico en nombre de la religión, exigiendo la debida sumisión de los católicos zacatecanos al nuevo emperador.

En un momento crítico para el imperio, ciertos eclesiásticos apoyaron públicamente a Iturbide de una manera enfática, mayor incluso de lo que

2 Todas las menciones a este documento se harán dentro del texto, entre paréntesis, indicando la(s) página(s) de donde procede la cita.

${ }_{3}^{3}$ Debemos mencionar aquí la Circular elaborada por fray Luis Carrasco, provincial de Santiago, el 25 de mayo de 1822, desde el convento de Santo Domingo de la ciudad de México. En ella exhortaba a que se realizaran misas en acción de gracias por la proclamación de Iturbide como emperador, cuya autoridad provenía directamente de Dios (Carrasco, 1822). No parece que exista conexión directa entre este documento y el sermón que nos ocupa. 
se pensaba. ${ }^{4}$ En este sentido, los sermones constituyen una pieza clave para reconstruir las cosmovisiones y los argumentos simbólicos con los que se pretendía sustentar la experiencia imperial (Connaughton, 2010, pp. 160-200; Herrejón, 2003, pp. 328-342; Terán, 2010). Como señaló Mariana Terán (1998, pp. 38 y 39), su capacidad para influir en quienes los escuchaban estaba condicionada por la autoridad del predicador, el hecho de que se pronunciaran en un espacio sagrado y atendiendo al motivo solemne que había animado su composición. A través de ese ritual, el público participaba de las ideas expresadas por el orador, quien buscaba hacer inteligibles las metáforas religiosas y las alegorías bíblicas que sustentaban su narración. La puesta por escrito de los sermones y, en su caso, su posterior impresión añadía a todo ello una mayor difusión del mensaje que se pretendía dar a conocer. La larga tradición sermonaria en Zacatecas así lo atestigua (Terán, 2002).

Por otro lado, es necesario atender al momento histórico en el que se pronunció el sermón que vamos a examinar para una lectura contextualizada del mismo. Las autoridades zacatecanas mantuvieron una relación bastante ambigua y compleja respecto de sus relaciones con Iturbide. En un primer momento, rechazaron el plan de independencia que este dio a conocer en Iguala, el 24 de febrero de 1821. En él se mantenía vigente la Constitución española de 1812 de manera transitoria, hasta que las futuras Cortes elaboraran una nueva. Ello fue visto por algunos como una amenaza a la capacidad de autogobierno que confería dicho código, a través de los ayuntamientos y las diputaciones provinciales. ${ }^{5}$ Por este motivo, el 11 de marzo, los miembros de la corporación municipal de Zacatecas lo consideraron como un proyecto "anticonstitucional". ${ }^{6}$ Fue la presión militar la que los llevó a aceptarlo y jurar la emancipación el día 5 de julio. Desde Aguascalientes, Pedro Celestino Negrete dirigió las operaciones, esperando obtener plata de las minas zacatecanas para el sostenimiento del ejército trigarante. Esa actitud interesada aumentó el recelo de las autoridades locales y propició el pronto surgimiento de grupos

${ }^{4}$ La actitud del clero durante el proceso de la independencia no fue homogénea, por lo que tampoco todos respaldaron a Iturbide (Connaughton, 2012; Ibarra, 2010). En el caso concreto de la alta jerarquía eclesiástica sí que encontramos un apoyo mayoritario a la emancipación, con la excepción del arzobispo Pedro José Fonte (García Ugarte, 2018; Pérez Memen, 2011).

${ }^{5}$ Sobre la Constitución de Cádiz y el liberalismo autonomista en México existe una abundante bibliografía (Benson, 1994; Chust, 2020; Frasquet, 2008; Rodríguez, 2001; Terán, 2020). También para el caso concreto de Zacatecas (Escobedo, 2019; Jacobo Bernal, 2016; Núñez Morales, 2000; Vega, 2005; Terán, 2007).

${ }^{6}$ Gaceta del Gobierno de México, 31 de marzo de 1821, núm. 42, pp. 325-326; Vega, 2005, p. 227. 
poco favorables a Iturbide (Moreno, 2010, pp. 397-398 y 2016, pp. 222, 224 y 272; Ortiz, 2014, pp. 259-260;). De hecho, la desconfianza hacia este no desapareció en los siguientes meses. A partir de febrero de 1822 se hicieron más evidentes las disputas entre iturbidistas, borbonistas y aquellos que empezaban a apostar por la senda del republicanismo (Ávila, 2004, pp. 121 y 122).

El Congreso constituyente contó con cuatro representantes por Zacatecas: Valentín Gómez Farías, José María Bocanegra, Agustín Iriarte y Francisco García Salinas. Este último se abstuvo en el momento de la proclamación de Iturbide como emperador. Los otros tres se encargaron de comunicar la noticia a su provincia el 22 de mayo, apremiando a que los ayuntamientos hicieran públicas y entusiastas manifestaciones a favor de aquel (Bocanegra, 1892, pp. 65 y 66). Desde el Colegio de San Luis Gonzaga, el brigadier José Francisco Sánchez informó que dichas nuevas llegaron a Zacatecas en la tarde del día 28 por correo extraordinario. ${ }^{7}$ Dos jornadas después las Actas de la diputación provincial recogían la negativa del ayuntamiento "a venir por esta excelentísima diputación para ir a la función celebrada en acción de gracias por la elección de nuestro emperador". Dicho desplante motivó que, a propuesta del doctor Mariano de Iriarte, "se elevara queja a su majestad sobre este particular" (Rojas, 2003, p. 58). Como vemos, no todos estaban de acuerdo con la manera en que Iturbide se había hecho con el poder, ni en la decisión tomada por el Congreso sin tener en cuenta la opinión de las provincias. Lo expuesto hasta aquí, de manera necesariamente sintética, revela la fragmentación política en Zacatecas a mediados de 1822 (Terán, 2021). El hecho de que el sermón, que va a ser objeto de atención, se predicara en ese ambiente muestra la inestabilidad del momento y la imperiosa necesidad de afianzar al nuevo emperador en el trono. La pervivencia de los imaginarios monárquicos y las esperanzas que algunos depositaban en Iturbide permiten complejizar, desde la perspectiva regional, el estudio de la cultura política en el periodo de la independencia. ${ }^{8}$

${ }^{7}$ Gaceta del Gobierno Imperial de México, 22 de junio de 1822, núm. 57, pp. 437 y 438.

${ }^{8} \mathrm{La}$ importancia de las culturas políticas monárquicas en el proceso de la emancipación de México se ha venido reforzando por parte de la historiografía (Cárabe, 2011; Guzmán, 2010; Landavazo, 2001; Pérez Vejo, 2008; Rojas, 2002). Metodológicamente, la influencia de la historia cultural en la renovación de los estudios sobre la historia política ha resaltado la centralidad de las representaciones mentales y de las imágenes simbólicas como categorías de análisis histórico. Estas resultan apropiadas para entender los contextos ideológicos, psicológicos y lingüísticos que permiten interpretar más cabalmente las motivaciones políticas de los actores. La crisis de la monarquía hispánica tuvo repercusiones sobre los viejos andamiajes mentales 
En las siguientes páginas analizamos los distintos argumentos que componen las tres partes del discurso religioso mencionado y sus diferentes significados. Con ello pretendemos comprender las ideas político-religiosas y las representaciones mentales que nutrieron las reflexiones del orador zacatecano. Su interpretación estaba basada en los supuestos intelectuales de aquellos eclesiásticos que compartían los imaginarios de la antiilustración. Vamos a situarnos, por tanto, en el ámbito de la contrarrevolución religiosa y en su afán por sostener la mancuerna Altar-Trono, aunque anteponiendo la preeminencia de la Iglesia. Ello nos muestra las reivindicaciones que realizaron ciertos eclesiásticos en el momento del imperio y las ilusiones depositadas en el mismo. El sermón contrarrevolucionario del que vamos a ocuparnos constituye una tipología de composición en la que la defensa de la ortodoxia católica y de los valores de la tradición estaba atravesada por las necesidades políticas del momento. Es decir, la apelación a viejos referentes se compaginaba con los recursos teóricos e intelectuales que los antirreformistas habían estado utilizando en su lucha contra las doctrinas que consideraban subversivas, desde antes de la revolución francesa. La necesidad de afrontar esa amenaza los llevó a abrirse hacia planteamientos novedosos en los que la intervención de los individuos en la esfera pública -con sus acciones y palabras- devenía un recurso de primera necesidad.

\section{LA FALSA FILOSOFÍA Y LA INDEPENDENCIA MEXICANA}

La primera parte del sermón estaba dedicada a explicar la sabiduría de los zacatecanos que habían prometido obedecer al emperador y le mostraban su apoyo. Como contrapunto a las virtudes de estos, el predicador se explayó en una extensa diatriba contra aquellos a los que situaba en sus antípodas ideológicas. Según su parecer, estos eran los mal llamados "filósofos" del día, apóstoles de la "filosofía inicua o revolucionaria" y enemigos declarados del orden, las instituciones, la religión y las monarquías. El orador no ahorraba epítetos a la hora de caracterizarlos como "falsos sabios", "regeneradores",

e idearios, al tiempo que abrió un proceso de cambio en el que la relación entre liberalismo y monarquía resultaría tensa, compleja y duradera, tanto en México como en España (Fernández Sebastián, 2014; Frasquet, 2016; García Monerris, Moreno y Marcuello, 2013). 
"novadores insensatos", "corifeos malvados" o "charlatanes" (pp. 6-9). De este modo, contraponía la conducta prudente de quienes respaldaban la forma de gobierno adoptada en el imperio mexicano frente a los que, supuestamente, buscaban introducir la confusión. Frente a estos publicistas, la "noble y fidelísima" ciudad de Zacatecas había dado muestras de su rechazo a las ideas de "anarquía" y a las "falsas doctrinas". Ella, añadía inmediatamente, "se conserva pacífica, persuasible a los consejos de bondad, amante de las leyes, sujeta a sus potestades y dócil a las insinuaciones de sus superiores" (p. 13). Quien pronunciaba estas palabras, como representante de Dios, pretendía erigirse en la voz de la comunidad a la hora de desacreditar a los perturbadores del statu quo. Sus palabras debían disuadir a quienes todavía anticiparan posibles beneficios de la Ilustración y el liberalismo. Conceptos como "humanidad, filantropía, derechos imprescriptibles del hombre, libertad, igualdad, fanatismo, superstición, rutina, antiguallas" constituían un "delirio" que había causado la ruina de numerosos reinos a lo largo del tiempo (p. 4). Para ello era menester explicar los orígenes de la secta filosófica, sus progresos en la monarquía hispánica y la reacción que habían propiciado en México, a partir de 1820.

El eclesiástico que elaboró este sermón participaba de aquello que se conoce como "la interpretación antiilustrada de la historia" (Herrero, 2020). Según dicho metarrelato, explicado en la pieza religiosa que estamos examinando, existía una conspiración de las fuerzas del mal y de la impiedad contra el bien y el catolicismo. El concierto y las jerarquías inspiradas por Dios habían sido cuestionadas desde sus orígenes por los secuaces de Satanás, enemigos de cualquier autoridad y acuerdo. Se trataba de una lucha universal que abarcaba todos los países y hundía sus raíces en la noche de los tiempos. Para el predicador había sido San Pablo, en su Epístola a los Colosenses 2:8, el primero en prevenir a los cristianos contra la filosofía y sus perniciosos planes. Esta era, según el Evangelio del apóstol Santiago 3:14-15, "aquella ciencia terrena, animal y diabólica” opuesta a la sabiduría que provenía del cielo. En las Sagradas Escrituras ya estaba anunciada esta guerra intemporal. Los verdaderos creyentes debían estar atentos y repudiar las ideas "inspiradas por el demonio enemigo del orden” (p. 10). De acuerdo con el orador, en el siglo XVI volvió a evidenciarse la presencia de estas doctrinas perniciosas. Durante los años de la reforma protestante se hicieron más visibles los proyectos de la hermandad filosófica contra el Altar y el Trono. Pero, sin duda, fue en el Setecientos cuando sus propósitos fueron conocidos por todos. Los 
ilustrados abanderaron un programa revolucionario que, bajo el pretexto de reforma, buscaba trastornar la vida política, social y religiosa. Los jefes de esta congregación eran Voltaire y Rousseau y sus emisarios se expandían por todo el continente europeo, llegando incluso a América. Los planes de estos alborotadores consistían en introducir el libertinaje, la absoluta igualdad y la tolerancia de cultos. Ello suponía un desafío a las autoridades monárquicas y religiosas, así como un cuestionamiento a todo principio de autoridad. ${ }^{9}$ Estos aspectos eran los que más incomodaban al predicador. La enseñanza de esa perversión servía como un contramodelo para reclamar fidelidad al emperador mexicano.

Según su narración, durante la revolución francesa se ensayó la aplicación de esta "humanísima y benéfica ciencia", cuyo funesto resultado era conocido por todos. El asesinato del rey Luis XVI supuso la entronización de los "hombres más viles e inhumanos". A ello se agregaron los terribles atentados cometidos contra la Iglesia y el desprestigio en que fueron sumidas las normas tradicionales que habían regido el país durante siglos. El trastorno era total. Los revolucionarios habían propiciado "la perdición de tantas vírgenes a quienes prostituyó el desenfreno lascivo de vuestros discípulos: la ruina de las familias, la destrucción de los templos, la impía persecución del sacerdocio, y el universal atropellamiento de todas las leyes, humana, divina y natural" (p. 10).

Estos eran los "triunfos" del filosofismo. Para el autor del discurso, quienes participaban de dichos principios eran los responsables exclusivos de semejante locura. La fuerza emocional de las descripciones sobre la persecución religiosa y el ajusticiamiento del monarca pretendían fomentar el desasosiego y el miedo entre los oyentes. Así, se buscaba crear un ambiente psicológico propicio para que prorrumpiera el odio contra los pretendidos enemigos de la estabilidad. Ninguna concesión era posible con ellos.

Al examinar el sermón, sorprende que el eclesiástico que lo preparó no integrara en su relato a otros grupos copartícipes de la conjura. A la altura de 1822 estaba muy arraigada entre los contrarrevolucionarios del espacio Atlántico la idea de que el complot de los falsos filósofos contaba con la estrecha colaboración de los francmasones y de aquellos que identificaban, de manera poco precisa, como jansenistas. Esas tres hermandades formaban parte de una liga internacional cuyas redes estaban preparadas para desestabilizar

${ }^{9}$ El miedo - real o figurado- a la difusión de estas doctrinas se dejó sentir fuertemente en Nueva España (Torres Puga, 2010). 
los gobiernos establecidos en cualquier momento (Ávila, 2009; Escrig Rosa, 2021). Esa teoría fabulosa, pero muy atractiva para los más conservadores, era perfectamente conocida en Zacatecas, tanto por la publicística antiliberal que entonces estaba circulando en todo el país como por las intervenciones públicas de otros oradores de la villa. Por ejemplo, el 11 de noviembre de 1821, fray Francisco García Diego (1822, pp. 11-22) dedicó la mayor parte de su sermón sobre la independencia a explicarla. ${ }^{10}$ Sin embargo, como decíamos, en el documento que nos ocupa no encontramos referencias a los otros miembros del contubernio revolucionario. Su atención se centraba de manera preferente y obsesiva en los filósofos. Sobre ellos recaía la culpabilidad total de los alborotos revolucionarios que habían tenido lugar en el último medio siglo. En este sentido, estamos ante un pensamiento heredero de la oposición al movimiento de las Luces y al cambio cultural que proponía. La mentalidad del eclesiástico estaba más cercana a la de los publicistas antiilustrados del siglo xviII que a los postulados intelectuales de los reaccionarios que le eran coetáneos. En este sentido, cabe preguntarse cuáles eran los referentes teóricos en los que se basada la primera parte del sermón y a qué autores se recurría para describir los fines de la falsa filosofía.

Quien elaboró esta pieza religiosa no tuvo reparo en esconder su fuente principal y exhibir una erudición que no era tal. De este modo, pretendía mostrar como propio un conocimiento que había plagiado de uno de los principales representantes del pensamiento reaccionario español, fray Rafael de Vélez (1777-1850). Concretamente, tomaba como referencia su afamado Preservativo contra la irreligión, o los planes de la filosofía contra la religión y el Estado, publicado por primera vez en Cádiz, en $1812 .{ }^{11}$ Dicho escrito había sido reeditado en

${ }^{10}$ El padre García Diego, a diferencia del orador desconocido, otorgaba en su análisis de la conspiración una importancia fundamental a los francmasones, a los que consideraba como cabecillas de toda revolución. Por ello afirmaba que podían nombrarse, indistintamente, "jacobinos, iluminados, regeneradores o filósofos falsos". Para analizar sus planes seguía de cerca al "gran" Agustín Barruel, afamado exjesuita autor de las Mémoires pour servir à l'histoire du jacobinisme (1797-1798). Esta obra fue un éxito editorial y se tradujo, en distintos momentos, al inglés, portugués, italiano, alemán, holandés, ruso y, por supuesto, al castellano. Las ficciones que llenan sus páginas fueron leídas por los reaccionarios como verdades reveladas (Herrero, 2020, pp. 191231; Hoffman, 1993). García Diego estaba utilizando la edición que realizó, en 1813-1814, el padre Raimundo Strauch, desde la isla de Mallorca. En Nueva España se conoció en 1800 a Barruel a través de la traducción de su polémica Histoire du clergé pendant la Révolution Française (1793).

${ }^{11}$ El título continuaba de la siguiente manera: realizados por la Francia para subyugar la Europa, seguidos por Napoleón en la conquista de España, y dados a luz por algunos de nuestros sabios en perjuicio de nuestra patria. Apareció en la Imprenta de la Junta de Provincia. 
México en 1813, en la Oficina de María Fernández de Jáuregui, a iniciativa de Agustín Pomposo Fernández de San Salvador. Después, en el contexto de la independencia, se imprimirían fragmentos manipulados del mismo en 1821 y $1822 .{ }^{12}$ Además, los eclesiásticos que prepararon sermones sobre la emancipación lo utilizaron con frecuencia, como es el caso del padre García Diego (1822, p. 19), a quien acabamos de aludir. Por tanto, estamos ante una obra que terminó también plenamente integrada en el contexto mexicano. Como señaló Javier Herrero (2020, p. 318), en este escrito encontramos "el primer tratado extenso dedicado a un análisis de la Ilustración, de la Revolución francesa y de las guerras napoleónicas, concebidas de forma exclusivamente reaccionaria", es decir, como parte del eterno conflicto entre religión y filosofía al que venimos refiriéndonos. El padre Vélez daba cuenta de haber leído a quienes le precedieron, en el último tercio del siglo anterior, en la tarea de descubrir los proyectos de los revolucionarios: Nicolas S. Bergier, Antonio Valsecchi, Fernando de Cevallos o Agustín Barruel. ${ }^{13}$ A partir de sus enseñanzas sistematizó los planes demoníacos de los sofistas de todos los tiempos para presentar un relato cohesionado que abarcaba desde los orígenes del cristianismo hasta las Cortes gaditanas. El liberalismo entraba así, también, a formar parte de las doctrinas de las sectas. Frente a ellas oponía toda la fuerza de la intolerancia y del fanatismo religioso (García Monerris y García Monerris, 2011). En estos materiales el eclesiástico zacatecano encontraba una cantera de referencias -históricas y ficticias- para elaborar su particular relato y presentarse ante el público como otro de los grandes apologistas. En este sentido, su voz pretendía llegar más allá del pueblo de Zacatecas.

A pesar del flagrante silencio respecto del Preservativo, este religioso sí que recomendaba la lectura de otra obra clave de la antiilustración. En este caso se trataba del Nuovo vocabulario filosofico-democratico indispensabile per ognuno che brama intendere nuova lingua rivoluzionaria (Venecia, 1799), del "célebre"

${ }^{12}$ He aquí los planes de la falsa filosofía contra la religión y el Estado. Puebla: Imprenta Liberal de Troncoso Hermanos (1821); y He aquí los planes de los falsos filósofos. México: Imprenta Americana de don José María Betancourt (1822). Ambos pueden encontrarse, respectivamente, en Ibero-Amerikanisches Institut (Berlín), Latin American Pamphlets from the Yale University Library, M90/14: 800189; y Biblioteca Nacional de México, fondo reservado, colección Lafragua, 215.

${ }^{13}$ Estos fueron autores, respectivamente, de las siguientes obras: Le Déisme refuté par luimême, ou examen, en forme de lettres, des principes dincredulite rapidness dan les divers ouvrages de M. Rousseau (1765), Dei fondamenti della religione e dei fonti dell'empietà (1765) y La falsa filosofía (1775-1776). Los trabajos de Barruel ya han sido comentados antes. Las ediciones de Bergier y Valsecchi fueron traducidas al castellano en 1777. 
jesuita Lorenzo I. Thujlen (1746-1833), cuyo nombre no se mencionaba en el sermón, probablemente por desconocimiento del autor. Dicho documento se había traducido al castellano en 1813 y fue objeto de diversas impresiones en España durante los periodos de restauración absolutista, pero su publicación en México no se produjo hasta 1834, en un contexto de reacción antiliberal (Rojas, 2012; Capellán de Miguel, 2017). La aportación de Thujlen pretendía ser una réplica satírica a la Encyclopédie de Diderot y D’Alembert para mostrar el trastorno que se había operado en el lenguaje por obra de los filósofos ilustrados, a los que consideraba como revolucionarios, republicanos, jacobinos y partidarios de la democracia. Los nuevos conceptos que poco a poco había ido incorporando el primer liberalismo -libertad, igualdad, pacto social, elecciones...-fueron impugnados por este fraile. Su defensa de los viejos términos y significados era también una apología de la monarquía absoluta y de la ortodoxia católica. En este sentido, el hecho de que en el sermón se invitara explícitamente a conocer la obra de Thujlen pone de relieve cuál era la filiación ideológica de su autor, aunque con algunos matices, como después veremos. Este eclesiástico esperaba que, tras la elección de Iturbide como emperador, se frenara en México cualquier tentativa revolucionaria.

Las dos obras que acabamos de mencionar servían al eclesiástico zacatecano para explicar la contaminación cultural y política que había tenido lugar en España en las últimas décadas. A su juicio, ello se había intensificado a raíz del ciclo liberal abierto en enero de 1820. Ese recorrido le permitía estimular un sentimiento de rechazo hacia dicho país. La puesta en vigor de la Constitución de 1812 y la apertura de las Cortes en Madrid retomaron la vía del cambio ensayada en el periodo de la asamblea gaditana (1810-1814). El objetivo era avanzar por la vía revolucionaria para desmantelar de manera definitiva el antiguo régimen. Los diputados emprendieron un programa de reforma eclesiástica que suscitó la inmediata oposición de los sectores contrarrevolucionarios. ${ }^{14} \mathrm{El}$ propio rey Fernando VII estuvo detrás de buena parte de las conspiraciones que entonces se urdieron para hacer naufragar la experiencia constitucional (Parra, 2018, pp. 375-474). Según el sermón, este cambio de régimen político había producido en Nueva España un amenazante "trastorno político y reli-

${ }^{14}$ Entre las medidas que más repercusión tuvieron destacan, entre otras, la abolición de la Inquisición y de los jesuitas, la disolución y reforma de las órdenes religiosas, el impulso desamortizador o la reducción del diezmo (Revuelta, 1973). Todo ello implicó el deterioro de las relaciones con Roma (Parra, 2020). 
gioso" que estuvo muy cerca de propiciar una "explosión general”. De manera similar a lo ocurrido durante la revolución francesa, esa perturbación habría causado "estragos horrorosos" entre la población. El "tumultuario procedimiento" con el que actuaban los revolucionarios no era del agrado de los americanos amantes de su religión. Por ello, añadía, estos estaban en contra de los "decretos impolíticos y antieclesiásticos dictados por la falsa filosofía" (p. 16). La única alternativa posible que encontraron como respuesta a estas disposiciones fue la proclamación de la independencia. Esta era una reacción meditada como resultado de "las deplorables experiencias de la Europa" (p. 11). Los fragmentos aquí recogidos llevaban a su autor a una apreciación definitiva: la España liberal debía ser abandonada a su propia suerte.

De este modo, el relato antiilustrado de la conspiración filosófica enlazaba con los argumentos que sostuvieron algunos contrarrevolucionarios mexicanos para explicar y justificar las causas de la emancipación. De acuerdo con su lectura del proceso histórico, la contaminación ideológica que se había venido produciendo en el continente europeo, como resultado de la difusión de las doctrinas ilustradas y liberales, avalaba la independencia del continente americano. De una forma utópica y bastante ingenua, los más conservadores imaginaban dicho espacio como un ámbito que podía mantenerse ajeno a la revolución. La ruptura con la monarquía española era el paso necesario para cortar los vínculos con las políticas liberales que impulsaban las Cortes madrileñas. Estamos ante un planteamiento ideal que no se correspondía de manera fehaciente con la realidad. La historiografía ha demostrado que la emancipación de México no supuso el cierre del proceso revolucionario, como así lo esperaban algunos de sus opositores, entre ellos el autor del sermón que estamos analizando. Tras la firma del Acta de Independencia, el 28 de septiembre de 1821, tanto la Junta Provisional Gubernativa, primero, como el Congreso constituyente, después, continuaron apostando por la senda del liberalismo gaditano, aunque no sin dificultades y resistencias (Ávila, 2014; Frasquet, 2008). De hecho, la Constitución española de 1812 estaba vigente en México cuando el orador zacatecano preparó su sermón, pero no la mencionó en ningún momento, seguramente porque no le despertaba simpatía alguna. Tampoco hizo alusión a los acalorados debates mantenidos en esos órganos legislativos, pues ello habría supuesto reconocer los triunfos de aquellos más cercanos al liberalismo revolucionario. En este caso, la omisión intencionada pretendía restarles importancia y poner el foco de atención en el nuevo emperador. 
Durante este complejo proceso, la figura de Iturbide estuvo en el centro de todas las miradas. Los más conservadores esperaban que fuera el adalid de la causa contrarrevolucionaria y el protector de sus intereses. Por eso algunos de ellos aplaudieron su elección como emperador y lo respaldaron con los medios que estaban a su alcance. De las altas expectativas en él depositadas da cuenta la segunda parte del sermón que abordamos en el siguiente epígrafe.

\section{LA SUBLIMACIÓN DEL HÉROE RELIGIOSO}

Desde que se dio a conocer el Plan de Iguala, la reputación de Iturbide fue en aumento en aquellas zonas que se adhirieron al proyecto independentista. Su carácter carismático y las declaraciones públicas que realizó en defensa del catolicismo y del rey Fernando VII le granjearon el apoyo inicial de una parte de los sectores más conservadores. Un nutrido grupo de eclesiásticos, aunque no sólo, se encargó de aunar en su persona las virtudes del adalid emancipador, del caudillo militar y del paladín religioso (Ocampo, 1969, pp. 66-83). Como recordaba de manera teatralizada el orador zacatecano, en esos días "Iturbide resonaba en las casas, calles y plazas de todos los lugares", porque, continuaba, "Iturbide era el asunto de las conversaciones más gustosas. Iturbide el objeto de las canciones más alegres. Iturbide el encanto de nuestros corazones" (pp. 20 y 21). Su elección como emperador exacerbó todavía más esta simbiosis (Rodríguez Moya, 2003). La dudosa legalidad de su encumbramiento y la ausencia de una tradición histórica que sustentara a la nueva dinastía imperial supusieron un desafío para aquellos que trabajaron en su legitimación. Pero el autor del sermón no se arredró ante estos retos. En su composición asoció la interpretación providencialista de la independencia mexicana a la exégesis bíblica, hasta convertir a Iturbide en un "caudillo" mesiánico. Sobre la base de este constructo pudo reclamar, una vez más, la obediencia al emperador electo y plantear, a su vez, cuál era, bajo su perspectiva, el modelo de monarquía más idóneo para el imperio. Sus palabras rebosaban optimismo y esperanza.

Esta segunda parte de la composición religiosa giraba en torno al sentimiento de la gratitud. Los zacatecanos debían reconocer los favores que les había hecho Iturbide y corresponder a ellos con su dócil sujeción. A través de una exageración de sus supuestas capacidades se proyectaba una imagen modélica del cabecilla militar al que todos debían plegarse. Bajo su liderazgo 
nada podía haber salido de manera incorrecta. El objetivo del orador era mostrar "las singulares proezas de nuestro héroe". De acuerdo con su impresión, el proyecto de independencia que abanderó dicho general condensaba la voluntad de liberar una patria oprimida, el respeto a los derechos de la Iglesia, el deseo de evitar un conflicto armado y la esperanza, en fin, de que todo ello revirtiera en favor de la felicidad definitiva de los mexicanos. Para completar dicho propósito, Iturbide tuvo que hacer frente a innumerables enemigos, insultos, desvelos y adversidades (p. 17). Todos los obstáculos puestos a sus planes constituían pruebas que fue superando. A través de ellas terminó elevándose por encima del resto hasta convertirse en el protagonista indiscutible de la emancipación. Su determinación por acabar con el imperio de la funesta filosofía merecía la admiración general:

Aquel Iturbide constante en los peligros, paciente en las persecuciones, consecuente en sus planes, manso y bondadoso para con sus enemigos, dulce en sus palabras, fuerte en la justicia que se versa, activo en sus operaciones, respetuoso a Dios y a su Iglesia, honrador de los ministros del santuario, celoso de las leyes santas, enemigo de la falsa ilustración del día, y diciéndolo en breve, formado como otro David a la medida de vuestro corazón (p. 18).

La equiparación del emperador mexicano con el rey israelita del Antiguo Testamento era toda una declaración de intenciones por parte del orador en sus planes por presentar una imagen sacralizada de aquel. El nombre de David significaba en hebreo "el elegido de Dios", del mismo modo que Iturbide había sido predestinado por la Providencia para dirigir la independencia de México. Como se anotaba en el sermón, dicho militar era un "instrumento de vuestra mano excelsa” (p. 18). Todo estaba prevenido en los planes del cielo: Dios fue el que dispuso que Fernando VII no aceptara finalmente la "corona de Anáhuac" y que las Cortes de Madrid rechazaran los Tratados de Córdoba. Así fue como quedó expedito el camino para que Iturbide pudiera ser aclamado emperador, de acuerdo con los sentimientos generales de la nación (p. 12). El predicador mostraba una confianza desmedida en el papel desempeñado por el líder trigarante en el proceso emancipador. En esa elaboración teórica se observa cómo Iturbide estaba ocupando el lugar y el protagonismo que en su momento tuviera el monarca español. Como es sabido, durante el cautiverio de Fernando VII en Valençay (1808-1814), a manos de Napoleón Bonaparte, se construyó la imagen de "el deseado"; es decir, de un monarca 
que, a su regreso, habría de reparar todos los males de la monarquía católica y conseguir la independencia de la península con respecto del ocupante francés (Alonso, 2015; Landavazo, 2001; Parra, 2011). De manera extrapolable, para el autor del sermón, Iturbide era quien había liberado a México de la opresión que ejercía España y, de manera especial, de sus impías Cortes. Además, sus éxitos le habían merecido llegar al puesto de emperador. En este sentido, el hecho de que el David bíblico hubiera sido el unificador del territorio israelita convertía, a su vez, a Iturbide en el Pater Patriae del México emancipado.

El uso de la hermenéutica analógica que estamos viendo, por medio de la cual se vinculaban estrechamente personajes y hechos de distintos momentos, era un recurso con larga tradición en el ámbito de la oratoria novohispana. A través de esa estrategia retórica el pasado se confundía con el presente de una forma selectiva, pero eficiente (Terán, 1998). En el sermón también se recordaba que en el momento de la independencia se presentó al general como un Alejandro Magno o el Judas Macabeo "de estos tiempos". Nos interesa reparar especialmente en esta segunda comparación. Según la tradición bíblica, el hijo del sacerdote Matatías fue el líder de una revuelta contra el imperio seléucida que le permitió recuperar el Templo de Jerusalén y liberar a Israel. Las facetas de próceres religiosos, militares y estrategas se fusionaban por igual en ambos personajes. Del mismo modo, la emancipación de México simbolizaba la recuperación de dicho espacio para Dios y su Iglesia. En muchos sentidos, la insistencia en la equiparación Israel/México remitía a los vaticinios que, desde el descubrimiento del continente americano, situaron proféticamente en dicho territorio la erección de una nueva ciudad de Dios (Gil, 1992, pp. 237-245; Lafaye, 2014, p. 401). Si en el pasado la monarquía hispánica fue adalid en la defensa y expansión del catolicismo, ahora, tras su irremediable declive, era el nuevo imperio mexicano el que iba a reemplazarla en esa tarea. Iturbide, al igual que los héroes bíblicos, había sido elegido para desempeñarla. Él era el "Ángel tutelar de la América" (p. 20).

Como estamos viendo, el orador zacatecano insistía en el exclusivo liderazgo del emperador en el rápido logro de la independencia. En su sermón no encontramos ninguna mención a los insurgentes ni a la revuelta que principiaron, bajo el liderazgo del cura Miguel Hidalgo, en septiembre de 1810. Esta elipsis pretendía poner el foco de atención en los sucesos de 1821 y correr un tupido velo respecto de los planes anteriores de emancipación. Ese año suponía el comienzo y el fin de la gesta emancipadora, así como el único momento que cabía recordar y conmemorar. Desde luego, este eclesiás- 
tico no compartía la propuesta republicana que los insurgentes maduraron, especialmente, a partir de 1814. Tampoco podía simpatizar con los principios liberales del Decreto Constitucional para la libertad de la América mexicana que promulgaron en Apatzingán, el 22 de octubre de dicho año. ${ }^{15}$ Su prototipo de gobierno apuntaba en otra dirección.

El autor del sermón celebraba que los diputados del Congreso se hubieran pronunciado en su primera sesión, el 24 de febrero de 1822, a favor de la monarquía moderada, aunque omitía anotar nada sobre su carácter constitucional. ${ }^{16}$ Según continuaba exponiendo, al soberano le correspondía gobernar de acuerdo con "las leyes justas que la misma nación americana forme por medio de sus sabios verdaderos, para conservar el orden, propiedades, quietud y paz de todos sus individuos”. A esas normas les incumbía contener y reprimir cualquier conato de subversión. Además, y ello era lo más importante, debían corresponderse con las leyes sagradas y las disposiciones de la Iglesia. En ningún caso podían apartarse u oponerse a ellas (p. 11). Como vemos, la filiación contrarrevolucionaria del predicador era compatible, en los momentos en que exponía su discurso ante los zacatecanos, con la existencia de un cuerpo representativo e, incluso, con algún tipo de ordenamiento constitucional, a pesar de que no pronunciara la palabra Constitución en ningún momento. En lo político, estamos ante un tipo de antiliberalismo pactista que ya había hecho acto de presencia en el tiempo de las Cortes de Cádiz. Frente a la arbitrariedad y el despotismo, era menester establecer ciertas normas que, de acuerdo con los postulados de la tradición y del catolicismo, regularan la vida del país y mantuvieran la completa estabilidad frente a cualquier veleidad revolucionaria. De hecho, la Representación y manifiesto que los diputados serviles presentaron a Fernando VII, en 1814, apuntaba en esa dirección (Calvo Maturana, 2018; López Alós, 2011, pp. 208-210). Respecto a la religión, aunque el liberalismo gaditano sancionó el carácter católico de la nación en el artículo 12 de la carta doceañista, para los contrarrevolucionarios ello consti-

${ }_{15}$ En Zacatecas, tras el golpe absolutista de 1814, algunos eclesiásticos como fray Antonio de la Luz Gálvez habían arremetido duramente contra la malhadada "Constitución mexicana". Aún así, el ambiente político antiliberal y represivo no fue óbice para que continuaran expresándose críticas al sistema (Terán, 2012, pp. 270-276).

${ }^{16}$ Ello difiere respecto al sermón predicado por Antonio Gálvez, en la parroquia de Zacatecas, el mismo día en que se instaló el Congreso. En él recordaba que la finalidad de los diputados era formar una Constitución propia para el imperio, con la asistencia de Dios. También reconocía el principio de soberanía nacional y la separación de los poderes (Gálvez, 1822). 
tuía una argucia. Rápidamente entendieron que la "protección" que allí se le consagraba estaba siendo utilizada por ciertos diputados para entrometerse en el ordenamiento de la Iglesia. Cuando se abolió el Tribunal de la Inquisición, en febrero de 1813, muchos de los reaccionarios que hasta entonces habían respetado el marco constitucional, incluso sin ser estrictamente simpatizantes del Santo Oficio, empezaron a ponerlo en cuestión y arremetieron contra los políticos de la asamblea (Parra, 1985). ${ }^{17}$ A partir de ese momento, para algunos antirreformistas el primer liberalismo se convirtió en un pecado, en un paradigma negativo de gobierno que era menester soslayar. Por ello el orador zacatecano evitó comentar nada sobre ese trascendental periodo.

En correspondencia con lo expuesto, el orador dejaba claro que las nuevas leyes del imperio mexicano deberían ser formadas por los "sabios verdaderos" que integraban el Congreso, lo cual suponía admitir, de manera implícita, que también había diputados que no merecían esa consideración. Es decir, rechazaba la concurrencia de los liberales revolucionarios en la formación de las futuras normas, de ahí que no mencionara los debates hasta entonces mantenidos. Además, por eso advertía de forma tan enfática que ninguna legislación podía ir en contra de la religión y de la Iglesia. El eclesiástico quería evitar así que se aprobaran decretos secularizadores, siguiendo el espíritu de las Cortes hispanas.

Por su parte, esta defensa a ultranza de la institución eclesiástica tenía también sus implicaciones respecto del emperador. De acuerdo con el orador, a Iturbide le correspondía ser el principal valedor de los intereses de aquella. En ningún caso debía "mezclarse en los asuntos de la Iglesia" ni "echar mano al turíbulo". Como católico, su deber era acatar las órdenes del papa y hacer que progresara "en lo temporal y espiritual" (p. 28). Este tipo de planteamiento

${ }^{17}$ En este punto, debemos hacer notar que, para el primer periodo liberal, suele confundirse erróneamente antiliberalismo con anticonstitucionalismo. Sin embargo, como señaló Carlos Ma Rodríguez López-Brea (2002, pp. 31-33) para el caso peninsular, perfectamente aplicable al novohispano, "muchos eclesiásticos no tuvieron problemas en jurar fidelidad a la Constitución, pero se hubieran indignado de recibir el apelativo liberal". Es decir, aceptaban la carta gaditana, en donde se les hacían importantes concesiones, a pesar de las objeciones que hemos visto, pero en ningún caso fueron cómplices del programa revolucionario que socavaba sus bienes y prerrogativas. Por ello señeros contrainsurgentes pudieron combatir el movimiento del cura Hidalgo a través de argumentos antiliberales, pero acatando la Constitución sin demasiados conflictos internos. Incluso se utilizaron los instrumentos legales que esta facilitaba contra los rebeldes. Huelga decir que los actores del momento no sabían que Fernando VII iba a dar un golpe de Estado en mayo de 1814, por lo que muchos se adaptaron a las circunstancias políticas. 
pretendía supeditar al emperador a las directrices de Roma y lo convertía, a su vez, en el brazo armado de Dios en la tierra. Él era el encargado de proteger la religión de los envites de la falsa filosofía y sus secuaces modernos, del mismo modo que en el pasado lo fueron los personajes bíblicos antes mencionados. Pero ello no le daba permiso para entrometerse en materias eclesiásticas y legislar sobre ellas. Frente a cualquier tentativa regalista, la Iglesia debía conservar su plena autonomía e independencia. El ultramontanismo subyacente a este planteamiento pretendía reforzar la posición de la institución eclesiástica por encima de cualquier instancia civil. Se trataba de una aspiración maximalista con la que el predicador buscaba revertir la pérdida de poder e influencia de la Iglesia, a la que se había venido asistiendo desde finales del siglo xviII. La independencia de México cobraba así, en su interpretación, un sentido trascendental: debía suponer el comienzo de un tiempo nuevo para aquella, ahora libre de cualquier intromisión en sus asuntos. ${ }^{18}$ El orador pensaba en una monarquía moderada y católica para el imperio que se cimentaba sobre unas premisas en las que la alianza Altar-Trono basculaba en favor del primer componente del binomio. En este sentido, el sermón pretendía definir las directrices políticas y religiosas a seguir en el nuevo país. La elección de Iturbide como emperador se convertía en un pretexto para aleccionar sobre el tipo de régimen que debía instaurarse.

Como podemos apreciar, el eclesiástico zacatecano aprovechaba la coyuntura para reclamar medidas que resultaran ventajosas a los de su misma clase. Entendía que ello era una recompensa debida por los denodados esfuerzos que algunos religiosos realizaron en favor de la causa independentista. Es decir, existía una conciencia de que la intervención pública de los eclesiásticos había facilitado la consecución de la ruptura con la monarquía española. En correspondencia, el emperador católico estaba obligado a premiar ese respaldo atendiendo a las necesidades de la Iglesia y las reivindicaciones de sus ministros. Sus líneas de actuación debían ir en una dirección contraria a las de las Cortes madrileñas y a los postulados de los liberales mexicanos que las seguían. Actuar de otra forma significaría traicionar el espíritu que los llevó a apostar por la emancipación. Ese paso trascendental no había terminado con

${ }^{18}$ El padre García Diego (1822, pp. 29 y 30), de manera acorde con otros oradores, aunque más enfáticamente, dio también cuenta de las ventajas que supondrían para la Iglesia, los eclesiásticos y la religión la ruptura con la España del Trienio Liberal. 
el mal filosófico y los planes de sus secuaces, motivo por el cual era menester permanecer en alerta.

\section{LOS PELIGROS DE LA PATRIA}

En la última parte del sermón, el orador realizó una exposición contrafactual de las desgracias que habrían supuesto para México el triunfo de los liberales revolucionarios y la no exaltación de Iturbide como emperador. Es decir, aplicó el mito de la conjura filosófica a las circunstancias del país emancipado. Se trataba de una síntesis de los argumentos antiilustrados que hemos examinado, pero ahora proyectados hipotéticamente sobre la realidad política del imperio, por lo que sólo atenderemos las aportaciones que se produzcan en este sentido. Dicho relato reforzaba la posición del emperador al presentar un escenario apocalíptico en caso de que no hubiera sido elegido como tal. Es más, observaba el predicador, el hecho de que existieran opositores a esa decisión demostraba que la situación todavía podía cambiar en un sentido desfavorable. Dios regía el curso de los acontecimientos, pero la fuerza de la secta conspiradora no podía combatirse sólo con plegarias. Los individuos debían intervenir de manera activa para derrotarla, poniéndose al servicio de Iturbide en esa tarea. Estas reflexiones giraban en torno al tema de la religiosidad de los zacatecanos, pues, de acuerdo con lo que hemos expuesto, la victoria de los conjurados supondría el éxito de sus doctrinas impías. De manera dicotómica, en el sermón se contraponían, una vez más, los "principios católicos" a los "proyectos revolucionarios". Ambos resultaban incompatibles y antagónicos: unos enseñaban orden y sumisión, los otros caos y rebeldía. Era preferible un castigo del cielo a la implementación de estos segundos:

Valía más que el Altísimo nos mandara una peste desoladora, una escasez nunca vista, o unos terremotos que nos sepultasen vivos, que no el que fuéramos regidos por filósofos de moda. Ellos en el momento, fingiéndose Católicos, Apostólicos, Romanos, según el uso hipócrita de sus antiguos maestros, tratarían de descatolizarnos a gran prisa con el pretexto de reformar los abusos que se han introducido en la religión, como ellos dicen (p. 26).

En eso consistía su "infernal plan". Los "liberales" mexicanos que lo querían poner en práctica sólo imitaban "los desatinos e impiedad de los libe- 
rales franceses" (p. 27). A través de esta equiparación se desacreditaba a todos aquellos políticos y publicistas críticos con los privilegios del clero. El orador zacatecano acudía a los argumentos contrarrevolucionarios para hacer frente al auge de la sátira anticlerical del momento (Covarrubias, 2008; Rojas, 1997). Los mecanismos de rechazo e inculpación contra los ilustrados -tanto reformistas como en su vertiente más radical- se adaptaban para criminalizar a los mexicanos que también pretendían acometer cambios en la organización de la Iglesia. Estos aspiraban al "desprecio general de todo el estado eclesiástico". Las fuentes "pestilentes" de las que se habían nutrido los delataban: Les ruines ou méditations sur les révolutions des empires (1791), del conde de Volney; Le Citateur (1803), de Pigault-Lebrun; o, Rousseau. También seguían de cerca la trayectoria del obispo Talleyrand, quien, como es sabido, se separó en 1791 de la Iglesia para entregarse al servicio del nuevo orden revolucionario. Todos, franceses y mexicanos, formaban parte de la trama contra el Altar y participaban de ideas subversivas, por lo que sus procedimientos eran ya bastante conocidos (p. 23).

En este sentido, a su vez, para el eclesiástico los enemigos de la patria pretendían minar el Trono atacando al emperador. El predicador se refería entonces a la conspiración que tuvo lugar a finales de 1821, en la que se proyectaba arrestar a Iturbide para que no pudiera seguir inmiscuyéndose en el proceso de convocatoria de las Cortes. En ese complot participaron liberales borbonistas, temerosos del poder que aquel pretendía concentrar, como primer regente, y republicanos (Ávila, 2004, pp. 89-90). Independientemente de su filiación, para el autor del sermón ellos eran hombres "sin carácter", "sin pudor", "llenos de dolo", "animados de su ilimitada soberbia y ambición" y, además, como no podría ser de otra forma, "penetrados de las luces falsas del día” (p. 23). Su formación filosófica y el ejemplo de los anteriores revolucionarios y regicidas era lo que los llevaba a despreciar al nuevo emperador y aspirar a minar su autoridad. El tono violento y el desbordamiento emocional que alcanzaba el sermón en este punto concluyente implicaban aceptar el ejercicio de la represión sobre los patriotas espurios. Como apuntamos, el propio orador entendía que su escrito era un correctivo contra estos. El púlpito se tornaba así en un medio desde el que se señalaba a los enemigos del imperio e involucraba a la comunidad en el acto de la depuración ideológica. Iturbide era el que debía abanderar esa campaña con fines regeneradores, al igual que lo hicieron en el pasado los caudillos del Antiguo Testamento que se enfrentaron a los enemigos de la religión. Ese llamamiento a la purga del 
suelo nacional lo había realizado también el padre Vélez en su Preservativo, por lo que el eclesiástico de Zacatecas conocía perfectamente los argumentos retóricos de la crueldad contrarrevolucionaria.

Una vez descubiertos los proyectos de los revolucionarios sobre México, el autor del sermón dirigía su atención a las consecuencias que acarrearía la puesta en vigor de los mismos. Planteaba tres posibles escenarios derivados de su ejecución. En primer lugar, el estallido de una guerra civil fratricida entre los buenos patriotas y sus perversos enemigos, que acabaría causando innumerables muertes. Ese conflicto, a continuación, traería aparejada la devastación del país como resultado de la discordia entre sus habitantes. Cuando esta se introducía en una sociedad podían esperarse funestos resultados. Con ella, decía el eclesiástico, "se llegan a ver los pueblos sin más orden que el que hay en los infiernos". La unión de los habitantes en torno a ciertas premisas básicas -como la patria, la religión o la monarquía- era esencial para evitar que proliferara el espíritu de facción. Esa cohesión debía también guiar las relaciones entre europeos y americanos, de acuerdo con el espíritu de la independencia. De lo contrario, México corría el riesgo de terminar como Francia en tiempos de la revolución, es decir, "dividida en partidos y regadas sus calles con la sangre de todos alternativamente". Ese era el drama al que se enfrentaban sus habitantes en caso de que los liberales se hicieran con el poder exclusivo. La concentración de sentires en torno al emperador constituía la forma más idónea para amortiguar el faccionalismo. Finalmente, lo expuesto llevaba al orador a considerar que, ante este devastador panorama, el territorio nacional quedaría irremediablemente expuesto a la posible invasión de cualquier otro país. Únicamente un liderazgo fuerte podía evitarlo. Indirectamente, el eclesiástico se hacía así eco de la campaña que Iturbide había promovido, en los momentos previos al golpe de Estado, para aumentar el número de efectivos en el ejército, aduciendo, como pretexto, la amenaza que supondría una campaña de reconquista por parte de España. El orador se valía de ese peligro -más figurado que real-para alentar el desasosiego (pp. 24 y 25). Sólo existía una opción para evitar semejante anarquía: estrechar los lazos de fidelidad con el emperador, respetarlo y obedecerlo en todo momento. Así debían comportarse los zacatecanos.

Con estas advertencias, el sermón cerraba su recorrido por los planes de los falsos filósofos desde los albores de la cristiandad. La elección de Iturbide como emperador había constituido un golpe a sus proyectos, pues este se debía encargar de revertir el proceso revolucionario. En nombre de 
Dios se apelaba a la obligatoria sumisión de todos los habitantes del imperio a su monarca. También se les incitaba a que aplacaran la voz de aquellos que cuestionaban su mandato y zaherían a los eclesiásticos. El mal filosófico no había desaparecido con la independencia. Aun así, a finales de mayo de 1822, el autor de la pieza religiosa esperaba que la llegada de Iturbide al trono supusiera el triunfo definitivo sobre las fuerzas del complot omnipresente. Aunque no sabemos cuál fue la reacción del eclesiástico en los meses posteriores, lo expuesto en estas páginas nos permite apuntar que la caída del imperio, en marzo de 1823, debió suponer una profunda frustración a las esperanzas de aquellos que, como él, vieron en el reinado de Iturbide la posibilidad de materializar sus planes contrarrevolucionarios.

\section{CONCLUSIONES}

En este trabajo nos hemos acercado a un sermón prácticamente desconocido entre los estudiosos de las piezas religiosas del periodo del primer imperio. $\mathrm{Su}$ existencia deja abierta la puerta a encontrar nuevos documentos de similar naturaleza en la coyuntura del Bicentenario de la Independencia de México. Sin duda, se trata de un momento oportuno para reflexionar, de manera más amplia, sobre el papel que desempeñaron la producción sermonaria y los eclesiásticos en el logro de la emancipación y en la llegada de Iturbide al trono. En el caso examinado nos hemos situado en la perspectiva ideológica de los antiilustrados y contrarrevolucionarios. En dicho sentido, resulta pertinente seguir investigando los motivos por los que algunos religiosos de filiación antiliberal apostaron, en 1821, por romper los lazos de unidad con la monarquía hispánica que hasta entonces habían sostenido. El miedo a la faceta secularizadora del proceso revolucionario y la convicción de que el rey Fernando VII estaría dispuesto a abandonar la España liberal alimentaron los anhelos de revertir el proceso revolucionario a través de la emancipación. Esos deseos dejaron paso también rápidamente a profundas decepciones, pues la ruptura con el gobierno español no implicó la paralización del periodo de transformaciones abierto en 1820. Pronto se hizo evidente que la Junta Provisional Gubernativa y el Congreso constituyente, integrados ambos por una mayoría de liberales, no iban a favorecer las demandas de los más conservadores sobre el completo blindaje del fuero eclesiástico o la reposición de los jesuitas y de las órdenes religiosas extintas. Tampoco se contempló la restauración del Tribunal de la 
Inquisición. Por su parte, el desconocimiento de los Tratados de Córdoba por los políticos peninsulares y la familia real frustró cualquier esperanza de que el monarca español u otro miembro de la familia Borbón se trasladara al imperio. Ello dejó la puerta abierta para que Iturbide pudiera ser proclamado emperador y contara con el respaldo de aquellos que, durante su reinado, y de una forma bastante idealista, esperaban ver cumplido el programa de la contrarrevolución. Más bien, como contrapartida, la llegada al trono de ese militar generó muchos recelos y cada vez mayores opositores.

Desde el particular contexto de Zacatecas se han visto los argumentos que un eclesiástico desconocido hasta ahora para nosotros sostuvo para reclamar fidelidad al emperador electo. Las divisiones políticas del lugar eran una proyección, en pequeña escala, de la creciente fragmentación ideológica del nuevo país. El sermón estudiado es una clara muestra de la confrontación entre distintos idearios político-religiosos y la disputa por imponerse al adversario e, incluso, dentro de aquellos grupos que compartían una similar cultura política. El apoyo incondicional que el orador ofrecía a Iturbide no implicaba una coincidencia de intereses. Su antiliberalismo eclesiástico le llevaba a reivindicar una posición preeminente para los religiosos en el nuevo Estado-nación. El emperador se situaba en la cúspide del poder como elegido de Dios, pero esa autoridad le era entregada para defender y beneficiar, de manera preferente, a la Iglesia y sus representantes. Se trataba de un esquema que nos muestra la inestabilidad de la mancuerna Altar-Trono, pues ambas instancias esperaban reforzar su posición, aún a costa de la otra. La alianza era necesaria y conveniente, pero podía resultar frágil cuando los intereses de quienes la sostenían entraban en cierta pugna. Por supuesto, el autor del sermón renegaba de aquellos políticos y publicistas que criticaban la posición privilegiada del clero. Su respeto coyuntural al Congreso constituyente no se traducía en simpatía por el liberalismo. De hecho, denunciaba explícitamente a los mexicanos que apostaban por esa ideología y los consideraba partícipes de los planes de la falsa Ilustración.

El potente mito de la conjura filosófica servía al eclesiástico para explicar el curso de los acontecimientos, en una amalgama de hechos reales e imaginarios. Aunque no los citara a todos, sus autores predilectos eran europeos porque entendía que conocían mejor las causas y los efectos del trastorno revolucionario. A través de sus análisis llegaba a la conclusión de que el viejo continente sucumbía irreversiblemente por la degeneración ideológica que habían introducido en él las nuevas doctrinas. Por el contrario, el continente 
americano, y de manera particular México, era el espacio donde resultaba posible un comienzo distinto a través de la independencia. Este optimismo contrarrevolucionario encontraba su refuerzo en una particular lectura de las Sagradas Escrituras. En sus pasajes podían encontrarse episodios y héroes que, de manera alegórica, servían para explicar y comparar los sucesos del momento. Es decir, las referencias bíblicas ayudaban a suplir las incertezas que suponían el inicio de la vida independiente y la elección de un nuevo emperador que no contaba con una legitimidad histórica y dinástica que lo avalara. El mundo de la religión se entreveraba con la realidad para presentar un relato que hiciera inteligible entre el público el rápido desarrollo de los acontecimientos. La división maniquea de la sociedad, entre buenos y malos patriotas, alentaba a excluir de la comunidad a aquellos que participaban de ideas subversivas contra el régimen establecido por voluntad de la Providencia. El orden inherente a los principios religiosos servía para reclamar sometimiento al emperador y desarticular las opiniones contrarias al mismo. En este sentido, esas premisas resultaban claves para el predicador a la hora de buscar un consenso en torno a la cuestionada figura de Iturbide. Las oposiciones a su mando por parte de ciertos sectores de zacatecanos impelían a que el discurso de la obediencia fuera contundente y amenazante.

Desconocemos los motivos por los que este documento nunca llegó a publicarse, a pesar de la utilidad que pudo haber tenido para reforzar la posición de Agustín I. Podemos sugerir tres hipótesis para explicarlo. En primer lugar, los argumentos contrarrevolucionarios esgrimidos por el autor del sermón probablemente no encontraron una acogida demasiado favorable entre la opinión pública de Zacatecas. Allí, la rápida deriva centrípeta del imperio fue contestada por aquellos liberales que se negaban a aceptar la disminución de su capacidad de autogobierno, lo cual abocaría a muchos de ellos hacia el republicanismo. La base político-ideológica de los reaccionarios resultaba frágil en el nuevo contexto, no obstante del potencial contestatario de sus discursos. A continuación, hemos de tener en cuenta que esa vocación centralizadora del emperador generó un progresivo desencanto entre algunos de los eclesiásticos más moderados que le habían apoyado. Iturbide solicitó de manera recurrente la ayuda económica del clero, especialmente a medida que proliferaron las insurrecciones en su contra. Ese requerimiento desgastó las relaciones con aquellos que aspiraban a la completa autonomía de la Iglesia, 
según lo habían expresado desde el momento de la independencia. ${ }^{19}$ Finalmente, cabe destacar que algunos religiosos mantuvieron una actitud cautelar durante todo el periodo imperial. Muchos apoyaron a Iturbide, pero fueron prudentes con la gestión de los tiempos. En este sentido, resulta ilustrativo que los sermones que se conocen con motivo de la coronación del emperador se pronunciaran en septiembre y diciembre de 1822, meses después de que se produjera el acto en la catedral metropolitana, en julio. Es más, la pieza oratoria que declamó en dicho momento el obispo de Puebla, Antonio Joaquín Pérez, no se imprimió hasta 1839. Tras la caída de Iturbide y el inicio de la República la memoria de la experiencia imperial, así como la de aquellos que contribuyeron a apuntalarla, quedó temporalmente relegada al plano del ostracismo. Ciertamente, las fuerzas conservadoras no fueron capaces de sostener al emperador en el trono.

En suma, con esta aportación se ha pretendido avanzar en el estudio de los imaginarios monárquicos en los primeros momentos del México independizado, remarcando que no existió un único modelo posible de monarquía. La emancipación abrió la posibilidad de que se idearan distintos órdenes posibles para el futuro inmediato del país. La riqueza de las vías alternativas que entonces se plantearon debe ser tenida más en cuenta por parte de la historiografía para seguir complejizando las investigaciones sobre el periodo. La mirada plural que proponemos debe integrar en sus análisis aquellas opciones disconformes con el ideario liberal y/o republicano. No se trata de una sustitución de paradigmas y perspectivas, sino de apostar por un enfoque que sea capaz de conjugar la relación dialéctica entre las distintas culturas políticas en formación. En este sentido, los sermones constituyen documentos privilegiados para aproximarse a las circunstancias del momento en que fueron elaborados y rastrear, así, las distintas sensibilidades ideológicas de quienes los enunciaron. Esa aproximación a los códigos mentales de los actores puede resultar útil para entender mejor sus motivaciones y las múltiples expectativas que depositaron en la independencia.

${ }^{19}$ Una muestra ilustrativa de esta erosión fueron las reticencias que exhibió Matías Monteagudo, señero canónigo de filiación antiliberal y colaborador de Iturbide, a que se continuara utilizando la plata de las iglesias para sostener al ejército. Ello quedó registrado el 7 de enero de 1823 (Bustamante, 2001). 


\section{LISTA DE REFERENCIAS}

Alonso, G. (2015). Imaginando a Fernando VII, rey católico y felón. Pasado y Memoria, 14, 57-77. DoI: https://doi.org/10.14198/PASADO2015.14.03

Amador, E. (1943) [1892]. Bosquejo histórico de Zacatecas (t. II). Zacatecas: Talleres Tipográficos "Pedroza".

Ávila, A. (2004). Para la libertad. Los republicanos en tiempos del Imperio, 1821-1823. México: Universidad Nacional Autónoma de México.

Ávila, A. (2009). Cuando se canonizó la rebelión. Conservadores y serviles en Nueva España. En E. Pani (coord.), Conservadurismo y derechas en la historia de México (t. I, pp. 43-85). México: Fondo de Cultura Económica/Conaculta.

Ávila, A. (2014). La Constitución de Cádiz en un “nuevo régimen”: México, 1821-1822. En R. Breña (ed.), Cádiz a debate: actualidad, contexto y legado (pp. 217-232). México: El Colegio de México.

Benson, N. L. (1994) [1955]. La Diputación Provincial y el federalismo mexicano. México: El Colegio de México/Universidad Nacional Autónoma de México.

Bocanegra, J. M. (1892). Memorias para la historia de México independiente, 1822-1846 (t. I). México: Imprenta del Gobierno Federal.

Burciaga Campos, J. A. (2011). Construyendo patria desde la Iglesia. Un sermón religioso en Zacatecas a favor de Agustín I. En E. Márquez, R. Araujo y R. Ortiz (coords.), Estado y nación en México. Independencia y revolución (pp. 379-394). Tuxtla Gutiérrez: Universidad de Ciencias y Artes de Chiapas.

Bustamante, C. M. (2001). Diario histórico de México, 1822-1848. México: El Colegio de México/ciesas.

Calvo Maturana, A. (2018). La Constitución de la monarquía: absolutismo y pactismo en el reinado de Carlos IV. En I. Frasquet y E. García Monerris (eds.), Tiempo de política, tiempo de Constitución. La monarquía hispánica entre la revolución y la reacción (1780-1840) (pp. 165-192). Granada: Comares.

Capellán de Miguel, G. (2017). Edición y estudio introductorio. En Nuevo vocabulario filosófico-democrático indispensable para todos los que deseen entender la lengua revolucionaria. San Millán de la Cogolla: Cilengua.

Cárabe, A. M. (2011). Como Dios manda. Las ideas monárquicas en el proceso de formación del Estado mexicano, 1808-1821. Morelia: Universidad Michoacana de San Nicolás de Hidalgo.

Carbajal, D. (2011). Una liturgia de ruptura: el ceremonial de consagración y coronación de Agustín I. Signos Históricos, 13(25), 68-99. Recuperado de https://signoshistoricos.izt.uam.mx/index.php/historicos/article/view/349 
Carrasco y Enciso, L. (1822). Circular que el Provincial de Santo Domingo dirige a los religiosos de su Provincia de Santiago de Predicadores del Imperio mexicano. México: Imprenta de don José María Ramos Palomera. Biblioteca de Colecciones Especiales Elías Amador (Zacatecas), núm. de control: 480317.

Chust, M. (2020). El fin del proyecto del autonomismo americano: Cortes versus independencias, 1820-1821. En M. Chust (ed.), 1821. México vs Perú (pp. 65-96). Madrid: Sílex.

Connaughton, B. (2010). ¿Politización de la religión o nueva sacralización de la política? El sermón en las mutaciones públicas de 1808-1824. En B. Connaughton (coord.), Religión, política e identidad en la independencia de México (pp. 160-200). México: Universidad Autónoma Metropolitana.

Connaughton, B. (2012). Ideología y sociedad en Guadalajara (1788-1853): La Iglesia católica y la disputa por definir la nación mexicana. México: ConAculta.

Covarrubias, J. E. (2008). Inútil e insociable: la Iglesia católica según la crítica sociológica de Fernández de Lizardi, Prieto y Ramírez, 1821-1876. En F. Savarino y A. Mutolo (coords.), El anticlericalismo en México (pp. 279-295). México: Cámara de Diputados/Tecnológico de Monterrey/Miguel Ángel Porrúa.

Escobedo, M. (2019). Oportunidades y retos de la transición política. Las autoridades de Zacatecas frente al cambio de régimen, 1808-1835. Rubrica contemporánea, 8(15), 25-43. DoI: https://doi.org/10.5565/rev/rubrica.169

Escrig Rosa, J. (2020). La coronación de Agustín I de México en los sermones religiosos impresos. Hispania Sacra, LXXII(146), 525-538. DoI: https://doi.org/10.3989/ hs.2020.039

Escrig Rosa, J. (2021). Contrarrevolución y antiliberalismo en la independencia de México (1810-1823). Zaragoza y Zamora: Prensas de la Universidad de Zaragoza/El Colegio de Michoacán.

Fernández Sebastián, J. (2014). Del rey cautivo a la república de derecho divino. Retóricas e imaginarios de las revoluciones hispánicas. En L. Rojas y S. Deeds (coords.), México a la luz de sus revoluciones (t. I., pp. 125-185). México: El Colegio de México.

Frasquet, I. (2008). Las caras del águila. Del liberalismo gaditano a la república federal mexicana (1820-1824). Castellón: Universitat Jaume I.

Frasquet, I. (2016). El primer liberalismo en Nueva España/México y la Revolución. En E. García Monerris, I. Frasquet y C. García Monerris (eds.), Cuando todo era posible. Liberalismo y antiliberalismo en España e Hispanoamérica, 1780-1842 (pp. 297325). Madrid: Sílex. 
Gálvez, A. (1822). Sermón que en 24 de febrero de 1822, día en que se instaló en la corte el soberano Congreso constituyente del imperio mexicano; y con tal motivo, predicó en la parroquia de Zacatecas el P. Fr. ... del orden de N. s. P. s. Francisco. Guadalajara: Imprenta de Sanromán/Centro de Estudios de Historia de México-CARso, núm. clasificador: 082.172.32 JAL, núm. inventario: 33722-C, observaciones: miscelánea Estado de Jalisco núm. 9, folleto 7.

García Diego, F. (1822). Sermón que en la solemnísima función que hizo este colegio de N. $S$. de Guadalupe de Zacatecas en acción de gracias por la feliz conclusión de la independencia del Imperio mexicano, dijo el P. Fr. ..., provincial apostólico y lector de artes en su mismo colegio, el día 11 de noviembre de 1821. Guadalajara: Imprenta de don Mariano Rodríguez/Centro de Estudios de Historia de México-CARso, núm. clasificador: 082.172.32 VA, núm. inventario: 33729-C, observaciones: miscelánea Estado de Jalisco núm. 10, folleto 2 .

García Monerris, E. y García Monerris, C. (2011). Palabras en guerra. La experiencia revolucionaria y el lenguaje de la reacción. Pasado y Memoria, 10, 139-162. DoI: https://doi.org/10.14198/PASADO2011.10.07

García Monerris, E., Moreno, M. y Marcuello, J. I. (coords.) (2013). Culturas políticas monárquicas en la España liberal. Discursos, representaciones y prácticas (1808-1902). Valencia: Publicacions de la Universitat de València.

García Ugarte, M. E. (2018) (coord.). Ilustración católica. Ministerio episcopal y episcopado en México (1758-1829) (vols. I y iI). México: Universidad Nacional Autónoma de México.

Gil, J. (1992) [1989]. Mitos y utopías del descubrimiento: I. Colón y su tiempo. Madrid: Alianza Editorial.

Gómez-Huerta Suárez, J. (2017). Iturbide “el breve”, primer emperador de México: el ceremonial de una coronación. Estudios Institucionales, 4(7), 91-106. DoI: https:// doi.org/10.5944/eeii.vol.4.n.7.2017.20175

Guzmán, M. (2010). ¿Monarquía, República o Imperio? La independencia de la Nueva España y el dilema de la constitución política de la nación, 1810-1821. Espacio, Tiempo y Forma, 22, 79-105. DoI: https://doi.org/10.5944/etfv.22.2010.1550

Hensel, S. (2012). La coronación de Agustín I. Un rito ambiguo en la transición mexicana del Antiguo Régimen a la independencia. Historia Mexicana, 61(4), 1349-1411. Recuperado de https://historiamexicana.colmex.mx/index.php/RHM/article/ view/223

Herrejón, C. (2003). Del sermón al discurso cívico, 1760-1834. Zamora: El Colegio de Michoacán/El Colegio de México. 
Herrejón, C. (2008) [1999]. Sermones y discursos en el Primer Imperio. En B. Connaughton, C. Illades y S. Pérez Toledo (coords.), Construcción de la legitimidad política en México en el siglo XIX (pp. 152-167). Zamora: El Colegio de Michoacán/Universidad Autónoma Metropolitana/Universidad Nacional Autónoma de México.

Herrero, J. (2020) [1971]. Los orígenes del pensamiento reaccionario español. Zaragoza: Prensas de la Universidad de Zaragoza.

Hoffman, A. (1993). Opinion, Illusion, and the Illusion of Opinion: Barruel's Theory of Conspiracy. Eighteenth-Century Studies, 27(1), 27-60. Dor: https://doi. org $/ 10.2307 / 2739276$

Ibarra, A. C. (2010). El clero de la Nueva España durante el proceso de independencia, 18081821. México: Universidad Nacional Autónoma de México.

Jacobo Bernal, J. E. (2016). Laboratorios de centralismo: el ayuntamiento zacatecano, 1820-1836. En M. Terán y E. Hurtado (coords.), Oscilaciones del federalismo mexicano: de la confederación a la República liberal (pp. 36-42). Zacatecas: Universidad Autónoma de Zacatecas/Taberna Libraria Editores.

Lafaye, J. (2014) [1974]. Quetzalcóatl y Guadalupe. La formación de la conciencia nacional. México: Fondo de Cultura Económica.

Landavazo, M. A. (2001). La máscara de Fernando VII. Discurso e imaginarios monárquicos en una época de crisis. Nueva España, 1808-1822. México: El Colegio de México/ UMSNH/El Colegio de Michoacán.

López Alós, J. (2011). Entre el trono y el escaño. El pensamiento reaccionario español frente a la revolución liberal (1808-1823). Madrid: Congreso de los Diputados.

Moreno, R. (2010). La consumación de la independencia en el norte: síntesis y reflexión. En A. C. Ibarra (coord.), La independencia en el septentrión de la Nueva España: Provincias Internas e intendencias norteñas (pp. 385-418). México: Universidad Nacional Autónoma de México.

Munro, W. (1983). Authority in Paul and Peter. The Identifications of a Pastoral Stratum in the Pauline Corpus and 1 Peter. Cambridge: Cambridge University Press.

Núñez Morales, M. (2000). De las Cortes de Cádiz al primer Congreso constituyente general y estatal de Zacatecas: nuevos actores políticos. (Tesis de maestría). Universidad Autónoma de Zacatecas, México.

Ocampo, J. (1969). Las ideas de un día. El pueblo mexicano ante la consumación de su independencia. México: El Colegio de México.

Ortiz, J. (2014) [1997]. Guerra y gobierno. Los pueblos y la independencia de México, 18081825. México: El Colegio de México/Instituto Mora.

Parra, E. La (1985). El primer liberalismo español y la Iglesia. Las Cortes de Cádiz. Alicante: Instituto de Estudios Juan Gil-Albert. 
Parra, E. La (2011). Fernando VII, el rey imaginado. En E. La Parra (coord.), La imagen del poder: reyes y regentes en la España del siglo XIX (pp. 29-76). Madrid: Síntesis.

Parra, E. La (2018). Fernando VII. Un rey deseado y detestado. Barcelona: Tusquets.

Parra, E. La (2020). 1820: ruptura entre la jerarquía eclesiástica y el Estado constitucional. Historia constitucional, 21, 5-26. DoI: https://doi.org/10.17811/hc.v0i21.664

Pérez Memen, F. (2011) [1972]. El episcopado y la independencia de México (1810-1836). México: El Colegio de México.

Pérez Vejo, T. (2008). Las encrucijadas ideológicas del monarquismo mexicano en la primera mitad del siglo xIx. En M. A. Landavazo y A. Sánchez Andrés (coords.), Experiencias republicanas y monárquicas en México, América Latina y España. Siglos XIX y Xx (pp. 327-347). Morelia: Universidad Michoacana de San Nicolás de Hidalgo.

Ramsey, Michael J. (1988). 1 Peter. En World Biblical Commentary (vol. 49). Nashville: Thomas Nelson.

Revuelta, M. (1973). Política religiosa de los liberales en el siglo XIX. Trienio Constitucional. Madrid: csic.

Robertson, W. S. (2012) [1952]. Iturbide de México. México: Fondo de Cultura Económica.

Rodríguez, J. E. (2001). Las Cortes mexicanas y el Congreso constituyente. En V. Guedea (coord.), La independencia de México y el proceso autonomista novohispano, 18081824 (pp. 285-320). México: Universidad Nacional Autónoma de México/Instituto Mora.

Rodríguez López-Brea, C. M. (2002). ¿Fue anticonstitucional el clero español? Un tópico a debate. Pasado y Memoria, 1, 5-42. DoI: https://doi.org/10.14198/ PASADO2002.1.11

Rodríguez Moya, I. (2003). Agustín de Iturbide, ¿emperador o héroe? En V. Mínguez y M. Chust (coords.), La construcción del héroe en España y México (1789-1847) (pp. 211-229). València: Publicacions de la Universitat de València.

Rojas, B. (2003) (ed.). La Diputación Provincial de Zacatecas. Actas de las sesiones de 18221823. México y Zacatecas: Instituto Mora/Gobierno del Estado de Zacatecas.

Rojas, R. (1997). Una maldición silenciada. El panfleto político en el México independiente. Historia Mexicana, 47(1), 35-67. Recuperado de https://historiamexicana. colmex.mx/index.php/RHM/article/view/2426

Rojas, R. (2002). La frustración del primer republicanismo mexicano. En J. A. Aguilar y R. Rojas (coords.), El republicanismo en Hispanoamérica. Ensayos de historia intelectual y política (pp. 388-423). México: Fondo de Cultura Económica/cIDE. 
Rojas, R. (2012). Viaje de un panfleto. Lorenzo Ignacio Thujlen y la lengua de la Revolución. Historia Mexicana, 62(2), 749-793. Recuperado de https://historiamexicana.colmex.mx/index.php/RHM/article/view/181

Sleeper, C. F. (1968). Political responsibility according to I Peter. Nouvum Testamentum, 10(4), 270-286. Dor: https://doi.org/10.2307/1560001

Terán, M. (1998). Sermones y tradiciones. Estado de la cuestión y propuestas de análisis. Caleidoscopio, 2(3), 37-56. Dor: https://doi.org/10.33064/3crscsh262

Terán, M. (2002). El artificio de la fe. La vida pública de los hombres del poder en el Zacatecas del siglo XVIII. Zacatecas: Universidad Autónoma de Zacatecas.

Terán, M. (2007). De provincia a entidad federativa: Zacatecas, 1768-1835. Zacatecas: Tribunal Superior de Justicia del Estado de Zacatecas.

Terán, M. (2010). Relatos de lealtad. Zacatecas: de la fortaleza amurallada por sus vasallos a la ciudad republicana. Relaciones, XXXI(121), 175-225. Recuperado de http://www. scielo.org.mx/scielo.php?script=sci_arttext\&pid=S0185-39292010000100007\&lng= es\&tlng=es

Terán, M. (2012). Por lealtad al rey, a la patria y a la religión. Zacatecas (1808-1814). Toluca: Fondo Editorial del Estado de México.

Terán, M. (2020). La revolución en el mundo hispánico. El peso del liberalismo gaditano en la obra de Jaime E. Rodríguez O. En I. Frasquet y V. Peralta (eds.), La revolución política. Entre autonomías e independencias en Hispanoamérica (pp. 217-235). Madrid: Marcial Pons.

Terán, M. (2021). De cántaros y juramentos. El trienio liberal en Zacatecas. En A. C. Ibarra, J. Ortiz y A. Tecuanhuey (eds.), Herrejón. Legado de la independencia mexicana. Xalapa: Universidad Veracruzana/unAm/BUAP (en prensa).

Torres Puga, G. (2010). Opinión pública y censura en Nueva España. Indicios de un silencio imposible, 1767-1794. México: El Colegio de México.

Vázquez Mantecón, M. del C. (2008). Las fiestas para el libertador y monarca de México Agustín de Iturbide, 1821-1823. Estudios de Historia Moderna y Contemporánea de México, 36, 45-83. Dor: https://doi.org/10.22201/iih.24485004e.2008.036.3191

Vega, Mercedes de (2005). Los dilemas de la organización autónoma. Zacatecas, 18081835. México: El Colegio de México. 


\section{OTRAS FUENTES}

\section{Hemerografía}

Gaceta del Gobierno de México, 31 de marzo de 1821, núm. 42.

Gaceta del Gobierno Imperial de México, 22 de junio de 1822, núm. 57. 